\title{
Aspects of International Public Procurement Regulation*
}

\author{
Pavla Neumannová, Ludmila Štěrbová \\ University of Economics, Prague, Czech Republic
}

\begin{abstract}
The public procurement market is classified as one of the most important segments of the world economy with share of $7-18 \%$ in the world GDP. The importance of this segment leads to continuous liberalization. Despite the existing legislative framework, the share of cross-border public procurement remains limited due to several obstacles including discrimination in public procurement that was raised by governments as one of the non-tariff barriers to international trade. Surveys of the European Commission or the European Bank for Reconstruction and Development (EBRD) indicate that there are many other obstacles to entry to international public procurement markets. These obstacles are discussed in the first chapter of this article. The goal of this paper is to review aspects of international public procurement regulation and find ways of eliminating the obstacles through this regulation. Therefore, the second, third, and fourth chapters of the paper analyse the WTO Government Procurement Agreement (GPA), the United Nations Commission on International Trade Law (UNCITRAL) Model Law on Public Procurement, and the role of regional trade agreements.
\end{abstract}

Keywords: cross-border public procurement, Government Procurement Agreement, revised GPA, World Trade Organization, UNCITRAL

\section{Introduction}

Despite fragmentation of available data, the World Bank classifies public procurement markets as one of the most important segments of world economy. The United Nations estimates the share of public procurement at $7-9 \%$ in the global gross domestic product (GDP); the International Monetary Fund at 10-18\%. The estimations of the size of the public procurement markets are also systematically calculated by the Organization for Economic Co-operation and Development and amount to $9 \%$ for the OECD member countries (Gourdon \& Messent, 2017). The importance of public procurement markets is reflected also in their continued liberalization through the plurilateral agreement of the World Trade Organization (Government Procurement Agreement [GPA]) and through regional trade agreements. In spite of quite robust legislative framework for international public procurement, the quoted sources consider the real share of cross-border public procurement as under its effective capacity.

Surveys of the European Commission or the European Bank for Reconstruction and Development (EBRD) indicate that there are obstacles to entry to international public procurement markets. These obstacles are

\footnotetext{
* Acknowledgement: This research paper is a part of the research project F2/70/2018 "Přeshraniční veřejné zakázky—analýza mezinárodního prostředí a překážky v zapojení českých firem" supported by the Internal Grant Agency (IGA) of the University of Economics, Prague.

Pavla Neumannová, Ph.D. student, interim academic staff, Faculty of International Relations, Department of International Business, University of Economics, Prague, Czech Republic.

Ludmila Štěrbová, Associate Professor, vice-chancellor, Faculty of International Relations, Department of International Business, University of Economics, Prague, Czech Republic.
} 
discussed in the first chapter of this article. The goal of this paper is to review aspects of international public procurement regulation and find ways of eliminating the obstacles through this regulation. Therefore, the second, third, and fourth chapter of the paper analyse the WTO Government Procurement Agreement, the United Nations Commission on International Trade Law (UNCITRAL) Model Law on Public Procurement, and the role of regional trade agreements.

\section{Cross-Border Public Procurement-Barriers to Entry}

Despite legislative framework, cross-border procurement remains limited at the international level, even in a single market, such as the European Union which is ruled by a common set of directives (OECD, 2013). The low share of cross-border public procurement indicates that there are still barriers to entry to international public procurement markets. The European Commission conducted a survey where approximately 270 European companies ( $\mathrm{N}$ between 260 and 274) evaluated several possible obstacles to cross-border bidding in the European Union. The obstacles were however formulated rather universally. Thus, the authors believe that the same obstacles can occur globally. According to the survey (European Commission, 2013), following obstacles (in the given order) were evaluated as the most relevant:

1. Lack of experience with doing business abroad;

2. Language barriers;

3. High extent of competition with national bidders;

4. Legal requirements leading to market entry barriers in the awarding country;

5. Cost level in general higher at home than abroad;

6. Resources necessary for participating in cross-border tender procedures higher compared to procedures in home country;

7. Unfamiliar formal requirements demanded;

8. Risks imposed by possible currency exchange rate fluctuations;

9. Additional costs due to geographic distance;

10. Different kinds of technical specifications that are demanded compared to experience in home country;

11. Tax or social insurance differences leading to cost disadvantages.

When it comes to small and medium-sized enterprises (SMEs), even other obstacles to entry may arise. Recent research in the EU as well as globally intensive discussion regarding public procurement policy features that may be causing a disproportionately small representation of SMEs in domestic and regional public procurement markets has taken place. For instance, it is argued that small businesses face higher costs in terms of regulatory compliance and unequal conditions in financial markets, and therefore in public tenders compete on unequal terms compared to large companies (EBRD, 2017).

The list of the most frequently discussed barriers faced by small businesses in participating and winning public sector contracts follows:

- Very large contracts;

- Insufficient access to information on business opportunities in public procurement;

- Lack of knowledge regarding public procurement procedures;

- Excessive bureaucracy;

- Limited experience in bidding;

- Expensive standards and certification requirements; 
- Disproportionate levels of technical qualification;

- Disproportionate levels of financial qualifications and incompatible payment terms;

- Unclear tender requirements;

- Lack of time to prepare bids;

- Preference for lowest price tenders;

- Centralisation of public procurement contracts;

- Lack of feedback from public buyers.

\section{WTO Government Procurement Agreement}

Since national governments worldwide reduced the use of tariff barriers to trade as a result of international trade agreements, many governments have raised non-tariff barriers in their place. According to Kono and Rickard (2013), one increasingly prominent non-tariff barrier is discrimination in public procurement. Chen and Whalley (2011) claimed that these discriminatory public procurement practices retarded the growth of world trade, and that is why the GPA has been signed. The GPA fulfilled the gap that has been left by the GATT and GATS agreements as they exempt from their rules governmental purchases of goods and services for the own use of governments. Using a gravity model on trade among GPA contracting parties, Chen and Whalley (2011) assumed that the GPA has a positive impact on bilateral trade in goods and services.

The discriminatory effect of public procurement practices has been addressed internationally in negotiations among developed countries since 70s of the 20th century and as a result, a Governmental Procurement Code on governmental good purchases has been signed by 12 governments. Its main contribution was non-discrimination and transparency approaches. On these principles, the plurilateral GPA became a part of the World Trade Organization agreements in 1995 and has been amended in 2014. The GPA is based on enhanced transparency, reciprocity in concessions of market access, good governance, and anticorruption principles. It covers procurement in goods and services including construction services; does not allow an application of the "buy local" provision; concerns both central and sub-central governmental bodies; and implements electronic procurement tools and procedures that enable access to information on public procurement. GPA sets requirements for notices, conditions for participation, qualification of suppliers, technical specifications and tender documentation, time periods for tendering and delivery, the use of negotiation and limited tendering, electronic auctions, treatment of tenders, and awarding of contracts (GPA, 2014). The GPA provisions should be implemented into the member states legislation and thus it has a direct impact on the national regulation.

Even if the concessions of members represent about 1.7 trillion USD annually (WTO, 2017), there are, however, some problems related to international trade in governmental purchases. The first one is the plurilateral nature of the GPA. As all the WTO members were not ready to sign the GPA in the end of the Uruguay round of negotiations, the agreements has currently 19 members including the EU; it is thus respected by 46 countries. Huge markets as the Chinese, Russian, Brazilian, or Indian ones are not part of it. Other problem is related to the fact that the members' commitments to open their market are limited to a quite high threshold values and only if the procuring entity that provides it is listed in the schedule of commitments. As a result, very many procurements are in reality open only to big companies that are in economic position to offer such extended supplies, and very many of procurements are not accessible for international suppliers at all. 


\section{UNCITRAL Model Law on Public Procurement}

The Model Law on Public Procurement contains procedures and principles aimed at achieving value for money and avoiding discrimination in the procurement process. As in the case of the GPA, the text promotes objectivity, fairness, participation and competition, and integrity towards these goals. Transparency is also a key principle, allowing visible compliance with the procedures and principles to be confirmed (UNCITRAL, 2011).

In 1994, UNCITRAL issued its Model Law on Procurement of Goods, Construction, and Services (the PP Model Law). In 2004, UNCITRAL's working group on procurement was tasked with updating the PP Model Law to reflect new procurement practices, in particular regarding electronic procurement (e-procurement) and related aspects of electronic commerce, and the experience gained in the use of the PP Model Law as a basis for legal reform (EBRD, 2018).

The Model Law allows government purchasers to take advantage of modern commercial techniques, such as e-procurement and framework agreements, to allow it to maximize value for money in procurement. The Law contains procedures to allow for standard procurement, urgent or emergency procurement, simple and low-value procurement, and large and complex projects (in which, and where appropriate, the government can interact with potential suppliers and contractors to obtain the best solution to its needs). All procedures are subject to rigorous transparency mechanisms and requirements to promote competition and objectivity. All decisions and actions taken in the procurement process can be challenged by potential suppliers. While the government purchaser therefore has discretion in deciding what to purchase and how to conduct the procurement that discretion is subject to safeguards that are consistent with other international standards—notably, those imposed by the United Nations Convention Against Corruption.

The Model Law allows the enacting State to pursue its domestic policy objectives-such as promoting economic development through the support of SMEs-to the extent that the government's international commitments allow.

The Model Law has also been prepared with a view to supporting the harmonization of international standards in public procurement, and takes account of the provisions of the WTO Agreement on Government Procurement, the European Union Directives (on procurement and remedies), the UN Convention Against Corruption, the Procurement Guidelines and Consultant Guidelines of the World Bank, and the equivalent documents of other IFIs.

The Model Law is aimed at assisting States in formulating a modern procurement law. Although developing countries and states whose economies are in transition were the main users of the 1994 text, the new Model Law reflects international best practice and is designed to be appropriate for all states (UNCITRAL, 2011).

\section{Regional Trade Agreements}

The World Bank defines a regional trade agreement as a treaty between two or more governments that determines the rules of trade for all signatories. Regional trade agreements (RTAs) are currently at the centre of many policy debates and are likely to shape trade and economic relations in the coming years (World Bank, 2018). RTAs also any longer remain so called "shallow" agreements that cover only tariffs or other border measures. RTAs are often deep agreements that cover a large set of policy areas that affect trade and 
investment in goods and services, competition policy, intellectual property rights, or government procurement rules.

Focusing on Regional Trade Agreements, Arrowsmith and Anderson (2011) defined three possible ways, how RTAs affect public procurement in general. RTAs either include detailed provisions regarding government procurement (these provisions are often analogous to the GPA) or include coverage commitments (in which case there is a strong correlation between this and the first option) or RTAs lack detailed chapters on public procurement, however, envisage the liberalization of procurement markets as objective. As the heading of this chapter indicates, we will mainly focus on whether the listed RTAs include coverage commitments. This is also demonstrated by Table 1 .

Table 1

A Broad Overview of Procurement Provisions in EU Free Trade Agreements

\begin{tabular}{|c|c|c|c|}
\hline FTA & $\begin{array}{l}\text { Inclusion of rules } \\
\text { analogous to the GPA }\end{array}$ & $\begin{array}{l}\text { Only short general } \\
\text { objective of opening }\end{array}$ & $\begin{array}{l}\text { Coverage } \\
\text { commitments }\end{array}$ \\
\hline EU -Central America* & yes & no & yes \\
\hline EU - Colombia -Peru* & yes & no & yes \\
\hline EU - Korea 2010 & $\begin{array}{l}\text { yes (Korea is GPA } \\
\text { signatory) }\end{array}$ & no & yes \\
\hline EU -CARIFORUM 2007 & yes & no & yes \\
\hline EU -Chile 2003 & yes & no & yes \\
\hline EU - South Africa 2000 & no & yes & no \\
\hline EU - Morocco & no & yes & no \\
\hline EU - Algeria & no & yes & no \\
\hline EU- Montenegro & no & yes & no \\
\hline EU - Lebanon & no & no & no \\
\hline EU - Ivory Coast 2008 & no & no & no \\
\hline
\end{tabular}

* Negotiated but not yet ratified

Note. Source: Public Procurement in International Trade, European Parliament (2012).

Detailed provisions of RTAs regarding public procurement may vary from treaty to treaty. Neumannová and Šterrbová (2018) analyzed agreements of five most important partners of the European Union in the EU extra trade including the Comprehensive Economic and Trade Agreement with Canada or the EU-South Korea Free Trade Agreement. Using these two examples, the authors state that RTAs are able to eliminate some of the barriers listed in the first chapter of this paper. As is the case with the Government Procurement Agreement, RTAs contribute to higher transparency, nondiscrimination and procedural fairness. The authors concluded that, 
besides other things, RTAs contribute to establishing single point of access, which makes the accessibility of public procurement notices easier.

Also, the commitments that may arise from the RTAs go often beyond the scope of the GPA. Therefore, RTAs open up new opportunities regarding a wider scope of covered entities or covered goods/services/construction services. According to the Comprehensive Economic and Trade Agreement (CETA), the Canadian commitments now cover the procurement of federal entities, provincial and territorial ministries and most agencies of government, crown corporations, regional, local and municipal governments and entities, which, according to the European Commission, represents the most comprehensive opening of public procurement market Canada has ever made (European Commission, 2016). Similarly, the EU-South Korea Free Trade Agreement also offers new opportunities to EU (and vice-versa to Korean) bidders. These additional areas, not covered in the GPA, are EU public works concessions and Korean so-called build-operate-transfer (BOT) contracts, such as key infrastructure projects from all central and subcentral entities committed by Korea under the GPA.

\section{Conclusion}

Cross-broader supplies in the area of governmental purchases represent a very interesting area for business; the national regulation of this market segment is however considered as being very protectionist and creates an obstacle that business cannot overcome easily. Existence of international rules of the governmental procurement environment should provide a good basis for an elimination of the mentioned barriers, but form a closer view it is clear that those rules apply for a certain part of the procurements.

The only international agreement that has legal impacts is the WTO Governmental Procurement Agreement that limitations lies in the membership consisting mostly of developed countries and in quite squeezed extend of procurements provided by specifically listed procurement entities. The procurements of a smaller amount that would be more accessible for small and medium sized enterprises are not open for international suppliers.

To overcome mentioned barriers, transparency of legal processes related to public procurement is one of the ways that can be helpful in this regard. The existence of the UNCITRAL Model Law on Public Procurement contributes to higher transparency of international environment. If implemented by national governments, the Model Law is of a significant contribution also for purchasers as it allows them to take advantage of modern commercial techniques, such as e-procurement and framework agreements. The Model Law has also been prepared with a view to supporting the harmonization of international standards in public procurement, and takes account of the provisions of the WTO Agreement on Government Procurement or the European Union Directives.

The last discussed milestone of the international regulatory framework is regional trade agreements. RTAs can affect public procurement in three different ways. They can include their own detailed provisions or further develop the provisions of the GPA. Thus, the RTAs are able to eliminate some of the listed barriers.

\section{References}

Arrowsmith, S., \& Anderson, R. D. (2011). The WTO regime on government procurement: Challenge and reform. New York: Cambridge University Press.

Chen, H., \& Whalley, J. (2011). The WTO government procurement agreement and its impact on trade. Retrieved February 8, 2018, from http://www.nber.org/papers/w17365 
European Bank for Reconstruction and Development (EBRD). (2017). Public procurement: Is open competition good for small and medium-sized enterprises? $\quad$ Retrieved December $9, \quad$ 2018, from https://www.ebrd.com/cs/Satellite?c=Content\&cid=1395256480342\&pagename=EBRD\%2FContent \%2FDownloadDocument

EBRD. (2018). Public procurement international standards. Retrieved December 9, 2018, from https://www.ebrd.com/what-we-do/sectors/legal-reform/public-procurement/international-standards.html

European Commission. (2013). Cross-border procurement above EU thresholds: DG for the internal market and services. $\begin{array}{llll}\text { Retrieved December } & \text { 9, 2018, from }\end{array}$ https://publications.europa.eu/en/publication-detail/-/publication/0e081ac5-8929-458d-b078-a20676009324

European Commission. (2016). CETA-Summary of the final negotiating results. Retrieved January 29, 2018, from https://trade.ec.europa.eu/doclib/docs/2014/december/tradoc_152982.pdf

European Parliament. (2012). Public Procurement in International Trade: DG for External Policies. Retrieved December 9, 2018, from http://www.europarl.europa.eu/RegData/etudes/etudes/join/2012/457123/EXPO-INTA_ET(2012)457123_EN.pdf

Gourdon, J., \& Messent J. (2017). How government procurement measures can affect trade. Paris: OECD Publishing. Retrieved December 9, 2018, from http://dx.doi.org/10.1787/d1ab07b8-en

GPA. (2014). Revised Government Procurement Agreement. World Trade Organization. Retrieved from https://www.wto.org/english/docs_e/legal_e/rev-gpr-94_01_e.htm

Kono, D. Y., \& Rickard, S. J. (2013). Think globally, buy locally: International agreements and government procurement. New York: Springer Science + Business Media New York.

Neumannová, P., \& Štěrbová, L. (2018). International public procurement market from the EU business perspective. Retrieved November 12, 2018, from https://ceeconference.vse.cz/wp-content/uploads/2018/05/proceedings2018.pdf

OECD. (2013). Implementing the OECD principles for integrity in public procurement: Progress since 2008. Paris: OECD Publishing.

United Nations Commission on International Trade Law (UNCITRAL). (2011). UNCITRAL model law on public procurement. $\begin{array}{llll}\text { Retrieved December } & 9, & 2018, & \text { from }\end{array}$ http://www.uncitral.org/uncitral/en/uncitral_texts/procurement_infrastructure/2011Model.html

World Bank. (2018). Regional trade agreements. Retrieved December 9, 2018, from https://www.worldbank.org/en/topic/regional-integration/brief/regional-trade-agreements

WTO. (1994). Agreement on government procurement. Retrieved November 12, 2018, from https://www.wto.org/english/docs_e/legal_e/gpr-94_01_e.htm

WTO. (2017). The revised WTO agreement on government procurement (GPA): Key design features and significance for global trade and development. Retrieved January 21, 2018, from https://www.wto.org/english/res_e/reser_e/ersd201704_e.pdf 